\title{
ANALISIS KORELASI KANONIK PADA PERILAKU KESEHATAN DAN KARAKTERISTIK SOSIAL EKONOMI DI KOTA PATI JAWA TENGAH
}

\author{
Diah Safitri ${ }^{1}$, Paramita Indrasari ${ }^{2}$ \\ ${ }^{1}$ Program Studi Statistika FMIPA UNDIP \\ ${ }^{2}$ Alumni Program Studi Statistika FMIPA UNDIP
}

\begin{abstract}
One of the general problem that is social and economics which not yet flatten and still meeting of low health case. To know the correlation between social and economics characteristic and behavior of health in Pati of Central Java is used the canonical correlation analysis. The variable that is taken are social and economics characteristic and behavior of health variable, which each consisting of nine indicator variable. Some assumptions like linearity, normal multivariable and do not multicolinearity should be fulfilled. After the assumption have fulfilled, data processing can be done so that obtained a conclusion. The result of canonical correlation analysis indicate that there is a signifikan correlation between social and economics characteristic variable and behavior of health variable. From nine indicator which forming variable of social and economics characteristic, earnings indicator variable, education of mother, expenditure and education of father giving the most dominant of contribution. While from nine behavior of health variable, indicator of balanced nutrient variable, physical activity, eradication of mosquito den, house floor, exclusive ASI, and brush teeth giving the most dominant of contribution.
\end{abstract}

Keywords : Social and Economics Characteristic, Behavioral of Health, Canonical Correlation Analysis

\section{PENDAHULUAN}

Kesehatan merupakan hak asasi manusia dan sekaligus merupakan investasi sumber daya manusia, serta memiliki kontribusi yang besar untuk meningkatkan Indeks Pembangunan Manusia (IPM). Kondisi sehat ini dapat dicapai dengan mengubah perilaku yang tidak sehat menjadi perilaku sehat dan menciptakan lingkungan sehat di rumah tangga, yang biasa disebut dengan Perilaku Hidup Bersih dan Sehat (PHBS). Perilaku hidup bersih dan sehat dapat diartikan bahwa dalam budaya hidup perorangan, keluarga dan masyarakat yang berorientasi sehat, serta bertujuan untuk meningkatkan, memelihara dan melindungi kesehatannya baik fisik, mental maupun sosial. Beberapa indikator Perilaku Hidup Bersih dan Sehat (PHBS) di rumah tangga yaitu ASI Eksklusif, penimbangan balita, gizi, sampah, lantai rumah, aktifitas fisik, tidak merokok, menggosok gigi dan PSN (pemberantasan sarang nyamuk).Ada beberapa faktor yang mempengaruhi status kesehatan yaitu lingkungan yang terdiri dari lingkungan fisik, sosial budaya, ekonomi, keturunan dan pelayanan kesehatan ${ }^{[7]}$.

Di sisi lain, terlihat bahwa pembangunan ekonomi yang telah dilakukan selama ini oleh pemerintah memang telah menghasilkan kemajuan di beberapa sektor-sektor ekonomi, namun bersamaan dengan itu juga tidak bisa dipungkiri masih ada kesenjangan sosial-ekonomi dalam masyarakat, dimana di satu sisi ada sebagian masyarakat yang mempunyai tingkat pendapatan dan tingkat pendidikan yang tinggi akan tetapi ada juga sebagian masyarakat yang tingkat pendidikan dan pendapatannya masih rendah bahkan banyak dari masyarakat tidak bisa memenuhi kebutuhan hidupnya sehari-hari dan berbagai 
masalah sosial ekonomi lainnya. Beberapa Karakteristik Sosial Ekonomi yaitu jumlah anggota keluarga, usia ayah, usia ibu, usia ayah saat menikah, usia ibu saat menikah, pendidikan ayah, pendidikan ibu, pendapatan dan pengeluaran.

Pembangunan di bidang kesehatan di Kabupaten Pati saat ini telah mencapai hasil yang cukup memuaskan, dilihat dari beberapa indikator keberhasilan terhadap peningkatan dalam pencapaian hasil program, walaupun masih ada beberapa penurunan pencapaian. Beberapa masalah umum yang masih dihadapi di kabupaten Pati adalah jumlah penduduk yang cukup besar, distribusi demografik yang belum merata dan tingkat pendidikan yang relatif belum memadai. Demikian pula keadaan lingkungan fisik dan biologi yang belum memadai, dimana penyakit menular masih diderita oleh sebagian penduduk, kesehatan ibu dan anak masih memerlukan perhatian yang besar dan khusus, karena masih banyak penyakit infeksi dan keadaan gizi masyarakat masih rendah yang ditandai masih dijumpainya kasus gizi buruk di beberapa desa.

Hal tersebut yang mendorong penulis untuk melakukan penelitian tentang hubungan perilaku kesehatan dengan karakteristik sosial ekonomi di Kota Pati Jawa Tengah dengan menggunakan analisis korelasi kanonik. Analisis korelasi kanonik dapat digunakan untuk melihat hubungan antara sekelompok variabel dependen $(Y 1, Y 2, \ldots, Y p)$ dengan sekelompok variabel independen $(X 1, X 2, \ldots, X q)$. Disamping itu, analisis korelasi kanonik juga mampu menguraikan struktur hubungan di dalam kelompok variabel dependen maupun di dalam kelompok variabel independen. Dalam penelitian ini, perilaku kesehatan merupakan variabel dependen sedangkan karakteristik sosial ekonomi merupakan variabel independennya. Jadi dengan menggunakan analisis korelasi kanonik, akan diketahui keeratan hubungan antara perilaku kesehatan dengan karakteristik sosial ekonomi di Kota Pati Jawa Tengah.

Analisis korelasi kanonik menggunakan data minimal berskala interval. Proses pengambilan data pada penelitian ini adalah dengan menggunakan wawancara dan pengisian kuesioner, diperoleh data berskala rasio sehingga analisis korelasi kanonik dapat dilakukan.

Variabel yang digunakan adalah Perilaku Kesehatan yang dalam penelitian ini berfokus pada Perilaku Hidup Bersih dan Sehat (PHBS) di rumah tangga, yang merupakan kelompok variabel dependen, yaitu ASI Eksklusif (Y1), penimbangan balita (Y2), gizi (Y3), sampah (Y4), lantai rumah (Y5), aktifitas fisik (Y6), tidak merokok (Y7), menggosok gigi (Y8), PSN (pemberantasan sarang nyamuk) (Y9). dan Karakteristik Sosial Ekonomi merupakan kelompok variabel independen yaitu jumlah anggota keluarga (X1), usia ayah (X2), usia ibu (X3), usia ayah saat menikah (X4), usia ibu saat menikah (X5), pendidikan ayah (X6), pendidikan ibu (X7), pendapatan (X8) dan pengeluaran (X9).

\section{TINJAUAN PUSTAKA}

\subsection{Analisis Korelasi Kanonik}

Analisis korelasi kanonik adalah salah satu teknik analisis statistik, yang digunakan untuk melihat hubungan antara segugus variabel dependen $\left(Y_{1}, Y_{2}, \ldots, Y_{p}\right)$ dengan segugus variabel independen $\left(X_{1}, X_{2}, \ldots, X_{q}\right)$. Analisis ini dapat mengukur tingkat keeratan hubungan antara segugus variabel dependen dengan segugus variabel independen. Disamping itu, analisis korelasi kanonik juga mampu menguraikan struktur hubungan di dalam gugus variabel independen ${ }^{[9]}$. Analisis korelasi kanonik berfokus pada korelasi antara kombinasi linear dari gugus variabel dependen dengan kombinasi linear dari gugus variabel independen. Ide utama dari analisis ini adalah mencari pasangan dari kombinasi linear ini yang memiliki korelasi terbesar. Pasangan dari kombinasi linear ini disebut fungsi kanonik dan korelasinya disebut korelasi kanonik. 


\subsection{Asumsi-asumsi dalam Analisis Korelasi Kanonik.}

Asumsi-asumsi dalam analisi korelasi kanonik adalah sebagai berikut:

a. Linearitas, yaitu keadaan dimana hubungan antara variabel dependen dengan variabel independen bersifat linear

b. Korelasi kanonik adalah hubungan linear antar variabel kanonik

c. Variabel independen dan variabel dependen berdistribusi Normal Multivariat

\subsection{Penentuan Fungsi Kanonik dan Pendugaan Koefisien Kanonik}

Misalkan ingin dibuat hubungan antara gugus variabel dependen $Y_{1}, Y_{2}, \ldots, Y_{p}$ yang dinotasikan dengan vektor variabel acak $\mathrm{Y}$, dengan gugus variabel independen $X_{1}, X_{2}, \ldots$, $X_{q}$ yang dinotasikan dengan dengan vektor variabel acak $\mathrm{X}$, dimana $p \leq q$. Misalkan, karakteristik dari vektor variabel acak $\mathrm{X}$ dan $\mathrm{Y}$ adalah sebagai berikut :

$$
\begin{array}{ll}
\mathrm{E}(\mathrm{Y})=\mu_{Y} & \operatorname{Cov}(\mathrm{Y})=\Sigma_{Y Y} \\
\mathrm{E}(\mathrm{X})=\mu_{X} & \operatorname{Cov}(\mathrm{X})=\Sigma_{X X}
\end{array}
$$

$$
\operatorname{Cov}(\mathrm{X}, \mathrm{Y})=\Sigma_{X Y}=\Sigma_{Y X}^{t}
$$

Kombinasi linear dari kedua gugus variabel tersebut dapat dituliskan sebagai berikut :

$$
\begin{aligned}
& \mathrm{W}=\underline{\mathrm{a}}^{t} \mathrm{X}=a_{1} X_{1}+a_{2} X_{2}+\cdots+a_{q} X_{q} \\
& \mathrm{~V}=\underline{\mathrm{b}}^{t} \mathrm{Y}=b_{1} Y_{1}+b_{2} Y_{2}+\cdots+b_{p} Y_{p}
\end{aligned}
$$

sehingga

$$
\begin{aligned}
& \operatorname{Var}(\mathrm{W})=\underline{\mathrm{a}}^{\mathrm{t}} \operatorname{Cov}(\mathrm{X}) \underline{\mathrm{a}}=\underline{\mathrm{a}}^{t} \Sigma_{X X} \underline{\mathrm{a}} \\
& \operatorname{Var}(\mathrm{V})=\underline{\mathrm{b}}^{t} \operatorname{Cov}(\mathrm{Y}) \underline{\mathrm{b}}=\underline{\mathrm{b}}^{t} \Sigma_{Y Y} \underline{\mathrm{b}} \\
& \operatorname{Cov}(\mathrm{W}, \mathrm{V})=\underline{\mathrm{a}}^{t} \operatorname{Cov}(\mathrm{X}, \mathrm{Y}) \underline{\mathrm{b}}=\underline{\mathrm{a}}^{t} \Sigma_{X Y} \underline{\mathrm{b}}
\end{aligned}
$$

Vektor koefisien $\underline{a}$ dan $\underline{b}$ dapat diperoleh dengan cara mencari $\rho_{1}{ }^{2}>\rho_{2}{ }^{2}>\cdots>\rho_{k}{ }^{2}$ yang merupakan nilai eigen dari matriks $\Sigma_{Y Y}^{-1} \Sigma_{Y X} \Sigma_{X X}^{-1} \Sigma_{X Y}$ yang berpadanan dengan vektor eigen $\underline{\mathrm{f}}_{1}, \underline{\mathrm{f}}_{2}, \ldots, \underline{\mathrm{f}}_{k}$. Disamping itu, $\rho_{1}{ }^{2}>\rho_{2}{ }^{2}>\cdots>\rho_{k}{ }^{2}$ juga merupakan nilai eigen dari matriks $\Sigma_{X X}^{-1} \Sigma_{X Y} \Sigma_{Y Y}^{-1} \Sigma_{Y X}$ yang berpadanan dengan vektor eigen $\underline{\mathrm{e}}_{1}, \underline{\mathrm{e}}_{2}, \ldots, \underline{\mathrm{e}}_{k}$. Sehingga vektor koefisien a dan $\mathrm{b}$ diperoleh sebagai berikut :

$$
\begin{array}{ll}
\underline{\mathrm{a}}_{1}=\frac{1}{\sqrt{\underline{\mathrm{e}}_{1}^{t} \Sigma_{X X} \underline{\mathrm{e}}_{1}}} \underline{\mathrm{e}}_{1} & \underline{\mathrm{b}}_{1}=\frac{1}{\sqrt{\underline{\mathrm{f}}_{1}^{t} \Sigma_{Y Y} \underline{\mathrm{f}}_{1}}} \underline{\mathrm{f}}_{1} \\
\underline{\mathrm{a}}_{2}=\frac{1}{\sqrt{\underline{\mathrm{e}}_{2}^{t} \Sigma_{X X} \underline{\mathrm{e}}_{2}}} \underline{\mathrm{e}}_{2} & \underline{\mathrm{b}}_{2}=\frac{1}{\sqrt{\sqrt{\underline{\mathrm{f}}_{2}^{t} \Sigma_{Y Y} \underline{\mathrm{f}}_{2}}} \underline{\mathrm{f}}_{2}} \\
\underline{\mathrm{a}}_{k}=\frac{1}{\sqrt{\underline{\mathrm{e}}_{k}^{t} \Sigma_{X X} \underline{\mathrm{e}}_{k}}} \underline{\mathrm{e}}_{k} & \underline{\mathrm{b}}_{k}=\frac{1}{\sqrt{\underline{\mathrm{f}}_{k}^{t} \Sigma_{Y Y} \underline{\mathrm{f}}_{k}}} \underline{\mathrm{f}}_{k}
\end{array}
$$

Korelasi kanonik diperoleh dengan menghitung :

$$
\operatorname{Corr}\left(\mathrm{W}_{k}, \mathrm{~V}_{k}\right)=\rho=\frac{\underline{\mathrm{a}}_{k}^{t} \Sigma_{X Y} \underline{\mathrm{b}}_{k}}{\sqrt{\underline{\mathrm{a}}_{k}^{t} \Sigma_{X X} \underline{\mathrm{a}}_{k}} \sqrt{\underline{\mathrm{b}}_{k}^{t} \Sigma_{Y Y} \underline{\mathrm{b}}_{k}}} \text { sebesar mungkin. }
$$

Didefinisikan pasangan pertama dari variabel kanonik adalah kombinasi linear $\mathrm{W}_{1}$, $\mathrm{V}_{1}$ yang memiliki ragam satu dan korelasinya terbesar; pasangan kedua dari variabel kanonik adalah kombinasi linear $\mathrm{W}_{2}, \mathrm{~V}_{2}$ yang memiliki ragam satu dan korelasi terbesar kedua serta tidak berkorelasi dengan variabel kanonik yang pertama dan pasangan ke-k dari variabel kanonik adalah kombinasi linear $\mathrm{W}_{\mathrm{k}}, \mathrm{V}_{\mathrm{k}}$ yang memiliki ragam satu dan 
korelasinya terbesar ke-k serta tidak berkorelasi dengan variabel kanonik 1, 2, .., k-1. Dengan demikian dapat dituliskan sebagai berikut :

- Fungsi kanonik pertama :

$$
\begin{array}{ll}
\mathrm{W}_{1}=\underline{\mathrm{a}}_{1}^{\mathrm{t}} \mathrm{X} & \operatorname{Var}\left(W_{1}\right)=1 \\
\mathrm{~V}_{1}=\underline{\mathbf{b}}_{1}^{\mathrm{t}} \mathrm{Y} & \operatorname{Var}\left(V_{1}\right)=1
\end{array}
$$

Maksimum Corr $\left(\mathrm{W}_{1}, \mathrm{~V}_{1}\right)=\rho_{1}$

- Fungsi kanonik kedua :

$$
\begin{array}{lll}
\mathrm{W}_{2}=\underline{\mathrm{a}}_{2}^{\mathrm{t}} \mathrm{X} & \operatorname{Var}\left(W_{2}\right)=1 & \operatorname{Cov}\left(W_{1}, W_{2}\right)=0 \\
\mathrm{~V}_{2}=\underline{\mathbf{b}}_{2}^{\mathrm{t}} \mathrm{Y} & \operatorname{Var}\left(V_{2}\right)=1 & \operatorname{Cov}\left(V_{1}, V_{2}\right)=0
\end{array}
$$

$\operatorname{Cov}\left(W_{1}, V_{2}\right)=\operatorname{Cov}\left(W_{2}, V_{1}\right)=0$ dan maksimum $\operatorname{Corr}\left(\mathrm{W}_{2}, \mathrm{~V}_{2}\right)=\rho_{2}$

- Fungsi kanonik ke-k :

$$
\begin{array}{lll}
\mathrm{W}_{\mathrm{k}}=\underline{\mathrm{a}}_{\mathrm{k}}^{\mathrm{t}} \mathrm{X} & \operatorname{Var}\left(W_{k}\right)=1 & \operatorname{Cov}\left(\mathrm{W}_{1}, \mathrm{~W}_{\mathrm{k}}\right)=0, \mathrm{k} \neq 1 \\
\mathrm{~V}_{\mathrm{k}}=\underline{\mathrm{b}}_{\mathrm{k}}^{\mathrm{t}} \mathrm{Y} & \operatorname{Var}\left(V_{k}\right)=1 & \operatorname{Cov}\left(\mathrm{V}_{1}, \mathrm{~V}_{\mathrm{k}}\right)=0, \mathrm{k} \neq 1
\end{array}
$$

$\operatorname{Cov}\left(\mathrm{W}_{1}, \mathrm{~V}_{\mathrm{k}}\right)=\operatorname{Cov}\left(\mathrm{W}_{\mathrm{k}}, \mathrm{V}_{1}\right)=0, \mathrm{k} \neq 1$ dan maksimum $\operatorname{Corr}\left(\mathrm{W}_{\mathrm{k}}, \mathrm{V}_{\mathrm{k}}\right)=\rho_{\mathrm{k}}$

\subsection{Proporsi Keragaman}

Besarnya nilai proporsi keragaman menunjukkan baik tidaknya variabel kanonik yang dipilih menerangkan keragaman asal. Semakin besar nilai proporsi keragaman ini menggambarkan semakin baik variabel-variabel kanonik yang dipilih menerangkan keragaman asal. Sedangkan batasan untuk nilai proporsi bersifat relatif, sebagai acuan yang cukup baik yaitu lebih besar dari $50 \%$.

\subsection{Uji Hipotesis}

Ada dua hipotesis yang akan diujikan dalam analisis korelasi kanonik yaitu uji hipotesis yang pertama untuk mengetahui apakah secara keseluruhan korelasi kanonik signifikan, jika pada uji hipotesis yang pertama memperoleh kesimpulan bahwa paling tidak ada ada satu korelasi kanonik tidak bernilai nol maka dilanjutkan dengan uji hipotesis kedua untuk mengetahui apakah ada sebagian korelasi kanonik signifikan.

- Uji korelasi kanonik secara bersama :

Hipotesis :

$H_{0}: \rho_{1}=\rho_{2}=\cdots=\rho_{k}=0$ (semua korelasi kanoniknya akan bernilai nol)

$H_{l}$ : ada $\rho_{i} \neq 0$ (paling tidak ada satu korelasi kanonik tidak bernilai nol) dimana $\mathrm{i}=1,2, \ldots, \mathrm{k}$

Statistik uji :

$$
\begin{aligned}
\mathrm{B}=-\left[n-1-\frac{1}{2}(p+q+1)\right] \ln \Lambda \\
\text { dengan : } \Lambda=\prod_{i=1}^{k}\left(1-\rho_{i}^{2}\right) \\
\mathrm{n}=\text { jumlah pengamatan }
\end{aligned}
$$

Kriteria keputusan : Hipotesis nol ditolak pada taraf signifikansi $\alpha$ jika B > $\chi_{\alpha}^{2}$ dengan derajat bebas pxq 
- Uji individu :

Hipotesis :

$$
\begin{aligned}
& H_{0}: \rho_{1}=0, \rho_{2}=0, \cdots, \rho_{k}=0 \\
& H_{1}: \rho_{i} \neq 0 \text { untuk } i=1,2, \ldots, k
\end{aligned}
$$

Statistik uji :

$$
\begin{gathered}
\mathrm{B}_{\mathrm{r}}=-\left[n-1-\frac{1}{2}(p+q+1)\right] \ln \Lambda_{r} \\
\text { dengan }: \Lambda_{r}=\prod_{i=r}^{k}\left(1-\rho_{i}^{2}\right) \\
\mathrm{n}=\text { jumlah pengamatan }
\end{gathered}
$$

Kriteria keputusan : Hipotesis nol ditolak pada taraf signifikansi $\alpha$ jika

$$
\mathrm{B}_{\mathrm{r}}>\chi_{\alpha}^{2} \text { dengan derajat bebas (p-r)(q-r) }
$$

\subsection{Interpretasi Fungsi Kanonik}

Interpretasi yang dapat dilakukan dalam analisis korelasi kanonik yaitu terhadap koefisien kanonik (bobot kanonik / weight kanonik), loadings kanonik dan cross loadings kanonik.

Weight kanonik merupakan koefisien kanonik yang telah dibakukan, dapat diinterpretasikan sebagai besarnya kontribusi variabel asal terhadap variate kanonik. Semakin besar nilai koefisien ini menyatakan semakin besar kontribusi variabel yang bersangkutan terhadap variate kanonik.

Loadings kanonik dapat dihitung dari korelasi antara variabel asal dengan masingmasing variabel kanoniknya. Semakin besar nilai loading mencerminkan semakin dekat hubungan fungsi kanonik yang bersangkutan dengan variabel asal.

Loadings kanonik variabel independen diperoleh dengan rumus sebagai berikut :

$$
\mathrm{R}_{\mathrm{Xw}}=\mathrm{R}_{\mathrm{Xx}} \mathrm{A}_{\mathrm{Z}}
$$

Sedangkan loadings kanonik variabel dependen diperoleh dengan rumus sebagai berikut :

$$
\mathrm{R}_{\mathrm{YV}}=\mathrm{R}_{\mathrm{YY}} \mathrm{B}_{\mathrm{Z}}
$$

Cross loadings kanonik dapat dihitung dari korelasi antara variabel asal dengan bukan variabel kanoniknya. Semakin besar nilai loading mencerminkan semakin dekat hubungan fungsi kanonik yang bersangkutan dengan variabel asal. Cross loadings kanonik variabel independen diperoleh dengan rumus sebagai berikut : $\quad \mathrm{R}_{\mathrm{Xv}}=\mathrm{R}_{\mathrm{Xw}} \rho_{k}$

Sedangkan Cross loadings kanonik variabel independen diperoleh dengan rumus sebagai berikut : $\quad \mathrm{R}_{\mathrm{YW}}=\mathrm{R}_{\mathrm{YV}} \rho_{k}$

\subsection{Redundansi}

Redundansi merupakan sebuah indeks yang menghitung proporsi keragaman yang dapat dijelaskan oleh variabel kanonik yang dipilih baik dari variabel kanonik dependen maupun variabel kanonik independen, yaitu sebagai berikut :

- Proporsi keragaman Y yang diterangkan oleh variabel kanonik V $\quad R_{(k) Y}^{2}=\frac{\sum_{k=1}^{p} r_{\hat{V}_{k}, Y_{j}}^{2}}{p}$

- Proporsi keragaman Y yang diterangkan oleh variabel kanonik $\mathrm{W} \quad R_{(k) Y \mid X}^{2}=\rho_{k}^{2} \cdot R_{(k) Y}^{2}$ 
- Proporsi keragaman X yang diterangkan oleh variabel kanonik W $R_{(k) X}^{2}=\frac{\sum_{i=1}^{q} r_{\hat{W}_{k} \cdot X_{i}}^{2}}{q}$

- Proporsi keragaman X yang diterangkan oleh variabel kanonik V $R_{(k) X \mid Y}^{2}=\rho_{k}^{2} \cdot R_{(k) X}^{2}$

Untuk menentukan fungsi kanonik yang dianggap cukup dalam menerangkan struktur hubungan $\mathrm{Y}$ dan $\mathrm{X}$ dilihat dari koefisien R-square. Nilai ini didapat dengan mengkuadratkan korelasi kanonik atau dapat dinotasikan sebagai berikut :

$$
R_{k}^{2}=\rho_{k}^{2}
$$

\section{HASIL DAN PEMBAHASAN}

\subsection{Penentuan Jumlah Sampel}

Populasi dalam penelitian ini adalah seluruh warga yang sudah berkeluarga di kawasan kota Pati, kurang lebih berjumlah 29144 rumah tangga. Karena dapat dipastikan bahwa populasi ini sangat besar jumlahnya, maka perlu dilakukan pengambilan sampel dengan mempertimbangkan keterbatasan masalah biaya, waktu dan geografis sehingga diputuskan pengambilan jumlah sampel sebanyak 150 responden. Pengambilan sampel dilakukan dengan menggunakan teknik purposive (judgement). Sampel sebanyak 150 responden diambil dari 29 desa yang berada di pati, dengan tidak menentukan (bebas) jumlah responden yang harus diambil untuk setiap desa.

\subsection{Cara Pengambilan Data}

Proses pengambilan data pada penelitian ini adalah dengan menggunakan wawancara dan pengisian kuesioner. Variabel yang digunakan adalah Perilaku Kesehatan yang dalam penelitian ini berfokus pada Perilaku Hidup Bersih dan Sehat (PHBS) di rumah tangga, yang merupakan kelompok variabel dependen, yaitu ASI Eksklusif (Y1), penimbangan balita (Y2), gizi (Y3), sampah (Y4), lantai rumah (Y5), aktifitas fisik (Y6), tidak merokok (Y7), menggosok gigi (Y8), PSN (pemberantasan sarang nyamuk) (Y9). dan Karakteristik Sosial Ekonomi merupakan kelompok variabel independen yaitu jumlah anggota keluarga (X1), usia ayah (X2), usia ibu (X3), usia ayah saat menikah (X4), usia ibu saat menikah (X5), pendidikan ayah (X6), pendidikan ibu (X7), pendapatan (X8) dan pengeluaran (X9).

\subsection{Uji Validitas dan Reliabilitas}

Sebelum diedarkan secara resmi, kuesioner akan diuji validitas dan reliabilitasnya dari 30 responden karena minimal pengambilan sampel untuk uji validitas dan reliabilitas adalah 30 responden. Tujuannya adalah untuk menguji apakah butir-butir pertanyaan yang mengukur variabel perilaku kesehatan sudah valid dan reliabel. Analisis dimulai dengan menguji validitas terlebih dahulu, baru diikuti uji reliabilitas.

Dengan sampel 30 responden, maka derajat bebas yang digunakan adalah $\mathrm{n}-2=$ 28 sehingga Nilai tabel Product_Moment $\mathrm{r}_{0.05,28}$ adalah 0.374 . Dari uji validitas diketahui bahwa setiap item pernyataan dalam kuesioner telah valid, karena nilai korelasi antara nilai setiap item pernyataan dengan total item setiap variabel secara berurutan adalah 0.643; $0.658 ; 0.710 ; 0.602 ; 0.556 ; 0.714 ; 0.533 ; 0.495$; dan 0.733 lebih besar dari nilai tabel Product_Moment $=0.374$ dan nilai signifikansi pada setiap variabel adalah $0.000<\alpha=$ 0.05. Jadi seluruh item pernyataan sudah valid dan membuktikan bahwa setiap item pernyataan telah dapat dianggap mampu mengungkap masalah yang ada. 
Uji reliabilitas dilakukan dengan terlebih dahulu membuang item pernyataan yang tidak valid. Karena semua item pernyataan valid maka uji reliabilitas dilakukan tanpa membuang item.Diperoleh nilai koefisien $\alpha$ (Cronbach Alpha) $=0.701>0.7$ sehingga dapat diambil kesimpulan bahwa variabel yang dibentuk sudah reliabel dan dapat dikatakan bahwa kuesioner yang dibagikan dapat memberikan data yang konsisten.

Setelah kuesioner dinyatakan valid dan reliabel, maka penelitian dapat dilakukan dengan menggunakan kuesioner ini.

\subsection{Pemeriksaan Asumsi}

Sebelum data diolah dengan menggunakan analisis korelasi kanonik, data harus memenuhi beberapa asumsi yaitu linearitas antar variabel, linearitas antar variabel kanonik, dan normal multivariat.

\section{- Linearitas antar Variabel}

Linearitas antar variabel independen dengan variabel dependen diuji dengan menggunakan Ramsey Test dengan hasil asumsi linearitas antar variabel terpenuhi.

- Korelasi kanonik adalah hubungan linear antar variabel kanonik Ada koefisien korelasi kanonik yang lebih dari 0.5 , berarti ada hubungan linear antar variabel kanonik.

- Normal Multivariat

Pengujian asumsi normal multivariat pada variabel independen dan variabel dependen dilakukan dengan melihat plot antara jarak mahalanobis yang diberi

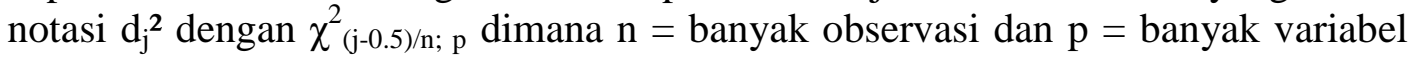
yang diberi notasi $\mathrm{q}_{j}$

Plot antara $\mathrm{d}_{\mathrm{j}}{ }^{2}$ dengan $\mathrm{q}_{\mathrm{j}}$ menunjukkan bahwa titik mendekati garis lurus, hal ini membuktikan bahwa sampel dapat diasumsikan berasal dari populasi normal multivariat.

Uji normal multivariat juga dapat dilakukan dengan uji Kolmogorov-Smirnov dari jarak mahalanobis $\left(\mathrm{d}_{\mathrm{j}}^{2}\right)$. Dengan menggunakan uji Kolmogorov-Smirnov untuk normal multivariat, variabel independen $p$-value $=0.0519>\alpha=0,05$ dan $\mathrm{DN}=$ $0.1103<D N^{*}(\alpha)=0.111$. Sedangkan variabel dependen $p$-value $=0.1201>\alpha=$ 0,05 dan $\mathrm{DN}=0.0968<D N *(\alpha)=0.111$ yang berarti bahwa variabel independen dan variabel dependen berdistribusi normal multivariat.

\subsection{Menurunkan dan Menaksir Fungsi Kanonik}

Korelasi kanonik dari gugus variabel dependen dengan gugus variabel independen menghasilkan 9 fungsi kanonik. Dalam memilih fungsi kanonik yang cukup digunakan untuk menjelaskan hubungan antara gugus variabel dependen dengan gugus variabel independen, selain berdasarkan uji statistik juga dapat dengan mempertimbangkan besarnya proporsi keragaman yang dijelaskan oleh fungsi kanonik dan besarnya korelasi kanonik.

- Besarnya Korelasi Kanonik

Nilai korelasi kanonik dari 9 fungsi kanonik menunjukkan bahwa koefisien yang besarnya lebih dari 0.5 terjadi pada fungsi kanonik pertama saja. Sedangkan fungsi kanonik kedua sampai dengan kesembilan, koefisiennya relatif kecil.

\section{- Proporsi Keragaman}

Batasan besarnya koefisien proporsi keragaman dapat dikatakan bisa digunakan untuk menerangkan keragaman total adalah bersifat relatif, sebagai acuan cukup baik yaitu lebih besar dari 50\%. Dengan demikian fungsi kanonik pertama saja yang baik dalam 
menerangkan keragaman total karena hanya fungsi kanonik pertama saja yang lebih besar dari $50 \%$.

\section{- Uji Statistik}

\section{(1)Uji Bersama-Sama (Kolektif)}

Setelah diuji dengan uji bersama-sama diketahui bahwa jika digabung secara bersama-sama fungsi kanonik signifikan, jadi fungsi kanonik pertama

\section{(2)Uji Individu} sampai dengan kesembilan bisa diproses lebih lanjut.

Berdasarkan uji individu diketahui bahwa korelasi kanonik pertama dan kedua yang berbeda nyata dengan nol maka fungsi pertama dan kedua secara individu bisa diproses lebih lanjut.

Dengan demikian, fungsi pertama dan kedua saja yang akan dianalisis lebih lanjut, karena signifikan secara individu dan bersama-sama walaupun pada fungsi kanonik kedua tidak mempunyai angka korelasi kanonik dan proporsi keragaman yang tinggi.

\subsection{Interpretasi Fungsi Kanonik}

\subsubsection{Weight Kanonik}

Berdasarkan koefisien kanonik yang telah dibakukan (dengan tidak memperhatikan fungsi ketiga sampai dengan kesembilan) diperoleh :

$>$ Pada fungsi kanonik pertama urutan kontribusi relatif variabel-variabel dependen terhadap variabel kanonik adalah Y6, Y3, Y1, Y9, Y8, Y2, Y7, Y4, Y5.

$>$ Sedangkan pada fungsi kedua, urutan kontribusi relatif variabel-variabel dependen terhadap variabel kanonik adalah Y1, Y3, Y6, Y4, Y2, Y9, Y5, Y8, Y7.

$>$ Pada fungsi kanonik pertama, urutan kontribusi relatif variabel-variabel independen terhadap variabel kanonik adalah X8, X7, X9, X6, X2, X4, X5, X3, X1.

$>$ Sedangkan pada fungsi kedua, urutan kontribusi relatif variabel-variabel independen terhadap variabel kanonik adalah X9, X7, X8, X2, X4, X5, X6, X3, X1.

\subsubsection{Loadings Kanonik}

Dengan tidak memperhatikan fungsi kanonik ketiga sampai dengan kesembilan :

$>$ Pada fungsi kanonik pertama, variabel-variabel yang hubungannya paling erat dengan variabel kanonik dependen yaitu Y3, Y6, Y9, Y5, Y1, dan Y8.

$>$ Pada fungsi kanonik kedua, variabel-variabel yang hubungannya paling erat dengan variabel kanonik dependen yaitu Y8, dan Y1.

$>$ Pada fungsi kanonik pertama, variabel-variabel yang hubungannya paling erat dengan variabel kanonik independen yaitu X8, X7, X9, dan X6.

$>$ Pada fungsi kanonik kedua, variabel-variabel yang hubungannya paling erat dengan variabel kanonik independen yaitu X9.

\subsubsection{Cross Loadings Kanonik}

Dengan tidak memperhatikan fungsi kanonik ketiga sampai dengan kesembilan :

$>$ Pada fungsi kanonik pertama, variabel-variabel dependen yang hubungannya paling erat dengan variabel kanonik independen yaitu Y3, Y6, Y9, Y5, Y1, dan Y8.

$>$ Pada fungsi kanonik kedua, tidak terdapat variabel-variabel dependen yang hubungannya paling erat dengan variabel kanonik independen.

$>$ Pada fungsi kanonik pertama, variabel-variabel independen yang hubungannya paling erat dengan variabel kanonik dependen yaitu X8, X7, X9 dan X6.

$>$ Pada fungsi kanonik kedua, tidak terdapat variabel-variabel independen yang hubungannya paling erat dengan variabel kanonik dependen. 


\subsection{Redundansi}

Dari hasil redundansi diperoleh nilai $\mathrm{R}^{2}$ kanonik dan besarnya proporsi keragaman $\mathrm{X}$ dan Y sebagai berikut :

Tabel 1.Koefisien Proporsi Keragaman Y yang Diterangkan

\begin{tabular}{|c|c|c|}
\hline $\begin{array}{c}\text { Fungsi } \\
\text { Kanonik Ke-i }\end{array}$ & $\mathrm{V}$ & $\mathrm{W}$ \\
\hline 1 & 0.3526 & 0.3142 \\
\hline 2 & 0.0859 & 0.0187 \\
\hline 3 & 0.0917 & 0.0126 \\
\hline 4 & 0.0724 & 0.0076 \\
\hline 5 & 0.0693 & 0.0051 \\
\hline 6 & 0.0713 & 0.0029 \\
\hline 7 & 0.0918 & 0.0017 \\
\hline 8 & 0.0956 & 0.0010 \\
\hline 9 & 0.0692 & 0.0001 \\
\hline
\end{tabular}

Tabel 2.Koefisien Proporsi Keragaman X yang Diterangkan

\begin{tabular}{|c|c|c|}
\hline $\begin{array}{c}\text { Fungsi } \\
\text { Kanonik Ke-i }\end{array}$ & $\mathrm{W}$ & $\mathrm{V}$ \\
\hline 1 & 0.3600 & 0.3208 \\
\hline 2 & 0.0544 & 0.0119 \\
\hline 3 & 0.1221 & 0.0167 \\
\hline 4 & 0.0978 & 0.0102 \\
\hline 5 & 0.0676 & 0.0050 \\
\hline 6 & 0.0726 & 0.0030 \\
\hline 7 & 0.1054 & 0.0019 \\
\hline 8 & 0.0490 & 0.0005 \\
\hline 9 & 0.0712 & 0.0001 \\
\hline
\end{tabular}

Dari hasil redundansi diperoleh nilai $\mathrm{R}^{2}$ kanonik adalah sebagai berikut :

Tabel 3.Koefisien Redudansi $\left(\mathrm{R}^{2}\right)$

\begin{tabular}{|c|c|}
\hline & $\begin{array}{c}\text { Koefisien Redudansi } \\
\left(\mathrm{R}^{2}\right)\end{array}$ \\
\hline 1 & $\mathbf{0 . 8 9 1 1}$ \\
\hline 2 & 0.2179 \\
\hline 3 & 0.1369 \\
\hline 4 & 0.1047 \\
\hline 5 & 0.0739 \\
\hline 6 & 0.0410 \\
\hline 7 & 0.0181 \\
\hline 8 & 0.0104 \\
\hline 9 & 0.0011 \\
\hline
\end{tabular}

Dari tabel 3 menunjukkan bahwa fungsi kanonik pertama saja yang memiliki koefisien redudansi tinggi, jadi hasil interpretasi dari fungsi pertama saja yang dapat digunakan. Sedangkan hasil interpretasi dari fungsi kedua tidak dapat digunakan.

Berdasarkan uraian sebelumnya analisis korelasi kanonik pada hubungan karakteristik sosial ekonomi dengan perilaku kesehatan menghasilkan variabel asal yang 
kuat dalam menjelaskan karakteristik sosial ekonomi adalah pendapatan (X8), pendidikan ibu (X7), pengeluaran (X9), pendidikan bapak (X6), dan variabel asal yang kuat dalam menjelaskan perilaku kesehatan adalah gizi seimbang (Y3), aktifitas fisik/ olahraga (Y6), PSN (Y9), lantai rumah (Y5), ASI eksklusif (Y1), menggosok gigi (Y8) .

\section{PENUTUP}

Analisis korelasi kanonik tepat digunakan dalam penelitian ini karena analisis korelasi kanonik digunakan untuk melihat hubungan antara sekelompok variabel dependen $(Y 1, Y 2, \ldots, Y p)$ dengan sekelompok variabel independen $(X 1, X 2, \ldots, X q)$.

Berdasarkan analisis korelasi kanonik dapat diperoleh hasil bahwa dalam hubungan perilaku kesehatan dan karakteristik sosial ekonomi di Kota Pati Jawa Tengah, variabel indikator pada variabel perilaku kesehatan yang dominan adalah variabel Gizi Seimbang, variabel Aktifitas Fisik/ Olahraga, Pemberantasan Sarang Nyamuk (PSN), Lantai Rumah, ASI Eksklusif dan Menggosok Gigi. Sedangkan variabel asal pada variabel Karakteristik Sosial Ekonomi yang dominan adalah variabel Pendapatan, variabel Pendidikan Ibu, variabel Pengeluaran dan variabel Pendidikan Bapak. Sehingga dapat dikatakan bahwa, semakin rendah karakteristik sosial ekonomi dalam hal Pendapatan, Pendidikan Ibu, Pengeluaran dan Pendidikan Bapak akan diikuti pula dengan menurunnya perilaku kesehatan khususnya dalam hal Gizi Seimbang, Aktifitas Fisik/ Olahraga, Pemberantasan Sarang Nyamuk (PSN), Lantai Rumah, ASI Eksklusif dan Menggosok Gigi dalam runah tangga tersebut.

\section{DAFTAR PUSTAKA}

1. Anderson, H. \& Tatham B. Multivariate Data Analysis Fitth Edition, Prentice-Hall International, Inc. New Jersey. 1998.

2. Dinas Kesehatan Propinsi Jateng, Pedoman Program Pembinaan Perilaku Hidup Bersih dan Sehat Tatanan Rumah Tangga, Dinkes Jateng. Semarang. 2006.

3. Dinas Kesehatan Kabupaten Pati, Profil Kesehatan Kabupaten Pati, Dinkes Kab. Pati. 2006.

4. Haryatmi, S. Buku Materi Pokok Statistik Multivariat, UT. Jakarta. 1988.

5. Jobson, J. D. Applied Multivariate Data Analysis Volume II : Categorical and Multivariate Methods, Springer-Verlag, Inc. New York. 1993.

6. Johnson, R. A. Applied Multivariate Statistical Analysis Fifth Edition, PrenticeHall International, Inc. New Jersey. 2002.

7. Notoatmojo, S. Promosi Kesehatan Teori dan Aplikasi, Penerbit Rineka Cipta. Jakarta. 2005.

8. Rencher, A. C. Multivariate Statistical Inference \& Applications. John Wiley \& Sons, Inc. New York. 1998.

9. Sartono, B. dkk. Analisis Peubah Ganda, Jurusan Statistika FMIPA-IPB.Bogor. 2003.

10. Sharma, S. Applied MultivariateTechniques, John Wiley \& Sons, Inc. New York. 1996.

11. Sugiyono. Statistika Untuk Penelitian, Alfabeta. Bandung. 2004.

12. Suliyanto, Analisis Data Dalam Aplikasi Pemasaran, Penerbit Ghalia Indonesia. Bogor. 2005. 